\title{
Malaysian Private Education Quality: Application of SERVQUAL Model
}

\author{
Anthony $\mathrm{Vaz}^{1} \&$ Shaheen Mansori ${ }^{2}$ \\ ${ }^{1}$ Faculty of Business, Communication and Law, Inti International University, Nilai, Malaysia \\ ${ }^{2}$ Graduate School of Business, Segi University, Kuala Lumpur, Malaysia \\ Correspondence: Shaheen Mansori, Graduate School of Business, Segi University, No. 9, Jalan Teknologi, \\ Taman Sains Selangor, Kota Damansara, PJU 5, 47810 Petaling Jaya, Selangor, Malaysia. Tel: \\ 60-303-6145-2777. E-mail:shaheen@segi.edu.my
}

Received: January 30, 2013 Accepted: February 26, $2013 \quad$ Online Published: March 22, 2013

doi:10.5539/ies.v6n4p164 URL: http://dx.doi.org/10.5539/ies.v6n4p164

\begin{abstract}
Intense competition among existing private education providers and the Malaysian government's relaxation of regulations for allowing international universities to open off shore campuses in Malaysia, have forced companies in the education industry to develop strategies which can help them to make their existing students satisfied and keep them loyal to the brand.

This paper, studied the impact of five factors of service quality (responsiveness, reliability, empathy, assurance, tangibility) on students' satisfaction at private universities and colleges. For this purpose 431 questionnaires were collected from different private education providers in Malaysia. The results indicated that tangibility has an influence on satisfaction followed by empathy; responsiveness and assurance have a direct and positive effect on students' satisfaction. However, reliability has not shown any impact of students' satisfaction.
\end{abstract}

Keywords: satisfaction, empathy, tangibility, responsiveness, reliability, assurance, SERVQUAL, private education

\section{Introduction}

\subsection{Introduce the Problem}

With the increasing number of colleges and university colleges in Malaysia and the Malaysian government's policy to open the market for foreign based universities since 2009, the education industry has given students (both local and international), several options to further their tertiary education. In addition, offering almost identical programmes by private colleges and universities (PCU) makes diversification very difficult. As a result, many PCUs try to diversify their brand compared to their competitors by providing higher quality services for their students. Customer satisfaction is one of the key indicators for a firms' financial success in a market. Studies have shown that high customer satisfaction can lead to higher retention rates and in the case of higher education, it can increase the intention of continuing at higher level studies (Anderson, Fornell, \& Lehmann, 1994; Auh \& Johnson, 2005; Berthon, Ewing, \& Napoli, 2008; Butt). Moreover, studies have shown that satisfied customers are willing to pay higher prices and they can be good ambassadors for a company to promote the brand by spreading good word of mouth (WOM). As a result many companies allocate a significant amount of money to monitor the level of satisfaction among their customers (Wangenheim \& Bayon, 2007; Wilson, 2002).

Even though, this issue seems obvious for most industries, it has become even more critical for Malaysian private education as the competition has become intense especially when supply is surplus to demand in recent years. Customer satisfaction has been studied by several researchers and in different industries. However, there is very little research that focuses on student satisfaction in Malaysia PUCs. Hence, as the education industry is different in nature compared to other industries and especially for the service industry, it is important for marketers to understand the factors that can influence students' satisfaction and the significance of each of them. Therefore this study will examine the relationship between five factors of service quality (Reliability, Tangibility, Responsiveness, Empathy and Assurance) known as SERVQUAL (Parasuraman, Zeithaml, \& Berry, 1988) to determine the student satisfaction level among undergraduate students. 


\subsection{Literature Review}

\section{Concept of Service Quality}

The service quality era began from the early 1980s but it was not until 1990s, that companies started focusing on this concept as the main cause of customer satisfaction/dissatisfaction (Chen \& Aritejo, 2008; Chun-yan, 2008; Gounaris, Stathakopoulos, \& Athanassopoulos, 2003).

One of the first studies in service quality was conducted by Parasuraman and colleagues (1988). They studied four service sectors (retail banking, credit card, securities brokerage and product \& repair maintenance) and introduced eleven dimensions and identified them as Reliability, Responsiveness, Customization, Credibility, Competence, Access, Courtesy, Security, Communication, Tangibles and Understanding or knowing the customer.

However, since there were some overlap across these eleven dimensions, the model was later modified and the factors decreased to Assurance, Empathy, Responsiveness, Reliability, Tangibles. The instrument was hence known as the SERVQUAL instrument (Parasuraman, et al., 1988). Assurances convey trust and confidence to customers as it refers to the knowledge and courtesy of the company's employees (Yap, Wong, Loh, \& Bak, 2010). In short, we refer this as a massage to customers about the staff (employees) of an organization by saying "We are sure of what we say and do". Empathy refers to personalized/individualized caring and the paying of attention by the staff (Kassim \& Abdullah, 2010). In other words, the company can provide for customers by conveying the massage to the customer that "We feel for you". Responsiveness refers to the level of willingness of the staff to provide acceptable and prompt service for customers (Lee, Kim, \& Ahn, 2011) to show that "We will get it done now". Reliability is the ability to provide the promised service on time, accurately and dependability (Kassim \& Abdullah, 2010). Reliability will bring this message to a customer from the company that "We deliver what we promise".

Tangibility refers to the company's physical facilities, staff appearance and medium of communications, for example signboards and notices (Naik, Krishna, \& Gantasala, 2010) and in simple words, the company wants to say to customers that "We can show it to you". The five dimensions of SERVQUAL have been used in different industries (for example in health care, education, retail banking and insurance) which confirm that this measurement is reliable and valid in different service industries (Brysland \& Curry, 2001; Kassim \& Abdullah, 2010; Lee, et al., 2011; Naik, et al., 2010; Sohail, 2003; Sohail \& Shaikh, 2004).

\section{Relationship between Service Quality and Customer Satisfaction}

Service quality and customer satisfaction are two similar concepts. Zeithaml et al., (1996) pointed out in their research that, service quality equals customer satisfaction to some extent because these two concepts are the comparison between customer's expectations and the actual service they receive. Oliver (2009) defined satisfaction as evaluations that customers give to business transactions. It is the gap between customer expectation and the actual service they receive. Expectation can be perceived as the short-term prediction of the service expected.

Zeithaml et al., (1996) suggested that both expectation and service quality can be on a one-time level or a cumulative level. The relationship between satisfaction and service quality is both temporary and long-term, especially in the education industry. At the university level, the minimum duration of relationship between students and institution is at least one year (for foundation and matriculation programmes) and at most can be up to 10 years if a student decides to continue upto post graduate and doctorate programmes.

The level of quality delivered by initiation can be measured through the quantitative scales of a company. However, from a student perspective, the level of service quality is a perception and it is very subjective (Gallifa \& Batalle, 2010). Therefore, it could easily be influenced by emotion, the environment and other factors and it can be shaped over a long period of time and destroyed in a minute (Siu \& Cheung, 2001). As a result of this study, we focus on the relationship between perceived service quality from students' perspective and the level of satisfaction of delivered service. Thus, for this study the following hypotheses have been developed.

H1: There is a positive and direct relationship between Assurance and Satisfaction

$\mathrm{H} 2$ : There is a positive and direct relationship between Empathy and Satisfaction

H3: There is a positive and direct relationship between Tangibility and Satisfaction

H4: There is a positive and direct relationship between Reliability and Satisfaction

H5: There is a positive and direct relationship between Responsiveness and Satisfaction 


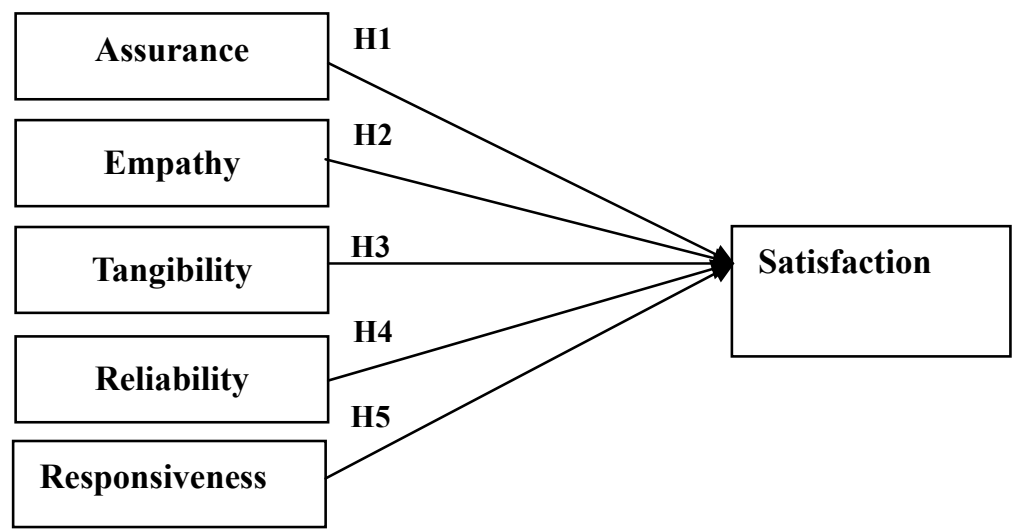

Figure 1. Theoretical model of study

\section{Methodology}

To test the model of this study, 431 questionnaires were collected from 3 different PUCs in Malaysia based on convenience sampling and from different faculties within each PUC. The questionnaire consisted of three parts, the first part focused on the service quality perception by adopting the SERVQUAL measurements and the second part measured the level of satisfaction of students. Finally, the last part of the questionnaire was dedicated to collecting demographic information of students such as the programmes undertaken, gender and other pertinent details.

\section{Results}

The result shows that $57.8 \%$ of participants were undergoing a degree, $18.1 \%$ from diploma, 15.3 degree transfer and $8.8 \%$ from pre-university programmes (see Table 1). The results from Table 2 show that all variables of this study follow a normal distribution as the skewness and kurtosis are within the acceptable range.

Table 1. Demographic factors

\begin{tabular}{|c|c|c|c|c|c|c|c|}
\hline & & Frequency & Percent & & & Frequency & Percent \\
\hline \multirow[t]{2}{*}{ Gender } & Male & 216 & 50.1 & Level & DEGREE & 249 & 57.8 \\
\hline & Female & 215 & 49.9 & & DIPLOMA & 78 & 18.1 \\
\hline \multirow[t]{2}{*}{ Nationality } & LOCAL & 356 & 82.6 & & $\begin{array}{l}\text { DEGREE } \\
\text { TRANSFER }\end{array}$ & 66 & 15.3 \\
\hline & INTERN & & 17.4 & & PRE-UNIVESITY & 38 & 8.8 \\
\hline
\end{tabular}

The results of validity and reliability test shows that all constructs meet the minimum requirement for validity as the Kaiser-Meyer-Olkin (KMO) measure of sampling adequacy shows significance at more than $70 \%$. Moreover, the results of reliability tests show that all construct have acceptable levels of reliability as 1) the Cronbach Alpha's of all constructs are above $70 \%$ and 2) the average variance expected was more than .5 and the composite reliability was more than .7 , which means the constructs have met the minimum threshold required (Hair, Black, Babin, Anderson, \& Tatham, 2010).

Table 2. Validity and reliability

\begin{tabular}{|c|c|c|c|c|c|}
\hline Variable & $\begin{array}{l}\text { Number of } \\
\text { Items }\end{array}$ & KMO/Sig & Cronbach Alphas & AVE & $\mathrm{CR}$ \\
\hline Tangibility & 8 & $.803 / .001$ & .741 & .400 & .818 \\
\hline Reliability & 6 & $.836 / .001$ & .836 & .558 & .882 \\
\hline Responsiveness & 5 & $.718 / .001$ & .769 & .528 & .884 \\
\hline Assurance & 4 & $.749 / .001$ & .722 & .557 & .834 \\
\hline Empathy & 3 & $.710 / .001$ & .765 & .680 & .864 \\
\hline Satisfaction & 4 & $.795 / .001$ & .825 & .660 & .886 \\
\hline
\end{tabular}


To test the hypotheses of this study the following linear model was run.

$\mathbf{Y}=\boldsymbol{\beta}_{0}+\boldsymbol{\beta}_{1} \mathbf{X}_{1}+\beta_{2} \mathbf{X}_{2}+\beta_{3} \mathbf{X}_{3}+\beta_{4} \mathbf{X}_{4}+\beta_{5} X_{5}+\varepsilon$

Where :

$\mathrm{Y}=$ Student satisfaction

$\beta_{0}=$ Constant

$\beta_{1}=$ The Slope along the Assurance

$\beta_{2}=$ The Slope along the Empathy

$\beta_{3}=$ The Slope along the Tangibility

$\beta_{4}=$ The Slope along the Reliability

$\beta_{5}=$ The Slope along the Responsiveness

$\mathrm{X}_{1}=$ Assurance

$\mathrm{X}_{2}=$ Empathy

$\mathrm{X}_{3}=$ Tangibility

$\mathrm{X}_{4}=$ Reliability

$\mathrm{X}_{5}=$ Responsiveness

$\varepsilon=$ Error

The results show that the model fits as the $\mathrm{f}$-value $=54$ and $\mathrm{p}$-value $<.001$. Moreover the adjusted R2 is around .4 which translates that $40 \%$ variance of the dependent variable (students satisfaction) can be explained by the 5 independent variables. Multi collinearity statistics results from table 5 show that there are no serious multi colorations among independent variables as the tolerances and VIF of all variables are within the acceptable range (tolerance $>.1$ and $\mathrm{VIF}<10$ ). It can indicate how well the SERVQUAL factors can predict overall satisfaction of students.

Table 3. Model summary

\begin{tabular}{lllll}
\hline Model & $\mathrm{R}$ & $\mathrm{R}$ Square & Adjusted R Square & Std. Error of the Estimate \\
\hline 1 & $.644^{\mathrm{a}}$ & .415 & .408 & .50894 \\
\hline
\end{tabular}

Predictors: (Constant), Perceive_Empathy, Perceive_Responsiveness, Perceive_Tangibles, Perceive_Reliability, Perceive_Assurance

Table 4. ANOVA $^{\mathrm{a}}$

\begin{tabular}{lllllll}
\hline Model & & Sum of Squares & df & Mean Square & F & Sig. \\
\hline \multirow{3}{*}{1} & Regression & 74.194 & 5 & 14.839 & 57.288 & $.000^{\mathrm{b}}$ \\
& Residual & 104.645 & 404 & .259 & & \\
& Total & 178.839 & 409 & & & \\
\hline
\end{tabular}

a. Dependent Variable: Overall_Satisfaction

b. Predictors: (Constant), Perceive_Empathy, Perceive_Responsiveness, Perceive_Tangibles, Perceive_Reliability, Perceive_Assurance

The results in table 5 shows that perceived tangibility has a direct and positive relationship with the level of satisfaction $(\beta=.297, p$-value $=.00001)$. This means that increasing one unit of higher perception about quality of tangible assets of the institution can increase around .3 of the satisfaction score for students. Moreover, regression results show that perceive reliability does not have a significant relationship with satisfaction $(\beta=.013$, p-value $=.7)$. 
Table 5. Coefficientsa

\begin{tabular}{|c|c|c|c|c|c|c|c|}
\hline \multirow[t]{2}{*}{ Model } & \multicolumn{2}{|c|}{$\begin{array}{l}\text { Unstandardized } \\
\text { Coefficients } \\
\end{array}$} & \multirow{2}{*}{$\begin{array}{l}\text { Standardized } \\
\text { Coefficients } \\
\text { Beta } \\
\end{array}$} & \multirow[t]{2}{*}{$\mathrm{t}$} & \multirow[t]{2}{*}{ Sig. } & \multicolumn{2}{|c|}{ Collinearity Statistics } \\
\hline & $\mathrm{B}$ & Std. Error & & & & Tolerance & VIF \\
\hline (Constant) & .646 & .140 & & 4.59 & .000 & & \\
\hline Perceive Tangibles & .297 & .050 & .293 & 5.93 & .000 & .594 & 1.68 \\
\hline Perceive Reliability & .013 & .046 & .015 & .28 & .775 & .510 & 1.96 \\
\hline Perceive Responsiveness & .124 & .047 & .136 & 2.66 & .008 & .559 & 1.78 \\
\hline Perceive Assurance & .113 & .046 & .130 & 2.43 & .015 & .507 & 1.97 \\
\hline Perceive Empathy & .193 & .047 & .217 & 4.10 & .000 & .517 & 1.93 \\
\hline
\end{tabular}

a. Dependent Variable: Overall Satisfaction

Perceived responsiveness shows a significant relationship with satisfaction $(\beta=.124, \mathrm{p}$-value $=.0008)$. The findings show that readiness to respond and the prompt responses from an institution are important for students in Malaysia. In addition, perceived assurance shows a positive and significant impact of students satisfaction $(\beta=.113, p$-value $=.015)$. Finally, the current results show that perceived empathy was positive and had a direct impact on students' satisfaction. This result indicated that one unit increase in perceived empathy received by students' side can increase about 2 units of satisfaction.

\section{Discussion}

As has been discussed, assurance refers to knowledge and courtesy, ability to convey trust and confidence from employees while empathy is caring or individualized attention provided to customer. Tangibles include the state of facilitating goods which include the physical condition of the buildings and the environment (appearance of physical facilities), and the appearance of personnel and communication materials (Parasuraman, et al., 1988).

According to the findings, tangibility has the highest effect on students' satisfaction. It means that facilities (buildings, library, classrooms and hostels) have the highest impact on students. Thus, PUCs' management should improve their assets and tangible facilities in order to make their students more satisfied. The second factor that has the highest influence on students' satisfaction is empathy. It shows that caring and individual attention is very important for students during their study and it can influence their level of satisfaction as they feel that the institution is trying to individualize services based on their personal needs.

The third factor which has a significant influence on level of students' satisfaction is responsiveness. This result indicates that prompt responses are very important for students. It shows that students really care about the promises from the institution and they want their institution to keep promises (written/unwritten) and deliver the services on time. In addition, the level of responsiveness is related to the lecturers/instructors actions toward students enquiries and questions and providing constructive feedback for coursework within a reasonable time. Thus, PUCs should provide suitable processes for students and lecturers to communicate and develop an appropriate quality assurance procedure in order to maintain quality in this area.

Perceived assurance is another factor that can influence student satisfaction. It can be interpreted that for students, this refers to knowledge of staff about the institution's product and services. Moreover, as assurance is also related to willingness and courtesy of staff; it can be elaborated that overall students value the willingness and courtesy to serve them as customers of a company.

This study conducted by applying convenience sampling only focus on three private education institutions in Malaysia. Therefore, to generalize the results of this study it is advisable to consider these limitations. In addition to improve the limitations of this study, further research should consider a bigger sample size from a wider range of private universities and colleges and use some method of qualitative approach ( for example projection, focus group) to get a better perspective of student satisfaction toward the private education quality in Malaysia. 


\section{References}

Anderson, E. W., Fornell, C., \& Lehmann, D. R. (1994). Customer satisfaction, market share, and profitability: Findings from Sweden. The Journal of Marketing, 58(3), 53-66.

Auh, S., \& Johnson, M. D. (2005). Compatibility effects in evaluations of satisfaction and loyalty. Journal of Economic Psychology, 26(1), 35-57.

Berthon, P., Ewing, M. T., \& Napoli, J. (2008). Brand Management in Small to Medium-Sized Enterprises*. Journal of Small Business Management, 46(1), 27-45. http://dx.doi.org/10.1111/j.1540-627X.2007.00229.x

Brysland, A., \& Curry, A. (2001). Service improvements in public services using SERVQUAL. Managing Service Quality, 11(6), 389-401. http://dx.doi.org/10.1108/09604520110410601

Butt, B. Z. (2010). A study examining the students satisfaction in higher education. Procedia-Social and Behavioral Sciences, 2(2), 5446-5450. http://dx.doi.org/10.1016/j.sbspro.2010.03.888

Chen, J. V., \& Aritejo, B. A. (2008). Service quality and customer satisfaction measurement of mobile value-added services: A conceptual review. International Journal of Mobile Communications, 6(2), 165-176. http://dx.doi.org/10.1504/IJMC.2008.016575

Chun-yan, T. (2008). Discussion on the People-based Concept and Service Innovation [J]. Sci-Tech Information Development \& Economy, 28.

Gallifa, J., \& Batalle, P. (2010). Student perceptions of service quality in a multi-campus higher education $\begin{array}{llll}\text { system in Spain. Quality Assurance in Education, } & \text { 18(2), }\end{array}$ 156-170.http://dx.doi.org/10.1108/09684881011035367

Gounaris, S. P., Stathakopoulos, V., \& Athanassopoulos, A. D. (2003). Antecedents to perceived service quality: an exploratory study in the banking industry. International Journal of Bank Marketing, 21(4), 168-190. http://dx.doi.org/10.1108/02652320310479178

Hair, J. F, Black, W., Babin, B., Anderson, R., \& Tatham, R. (2010). Multivariate data analysis. New Jersy: Pearson Education.

Kassim, N., \& Abdullah, N. A. (2010). The effect of perceived service quality dimensions on customer satisfaction, trust, and loyalty in e-commerce settings: A cross cultural analysis. Asia Pacific Journal of Marketing and Logistics, 22(3), 351-371. http://dx.doi.org/10.1108/13555851011062269

Lee, J., Kim, H. J., \& Ahn, M. J. (2011). The willingness of e-Government service adoption by business users: The role of offline service quality and trust in technology. Government Information Quarterly, 28(2), 222-230. http://dx.doi.org/10.1016/j.giq.2010.07.007

Naik, C., Krishna, G. S. B., \& Gantasala, V. (2010). Service quality (SERVQUAL) and its effect on customer satisfaction in retailing. European Journal of Social Sciences, 16(2), 231-243.

Oliver, R. L. (2009). Satisfaction: A behavioral perspective on the consumer: ME Sharpe Inc.

Parasuraman, A., Zeithaml, V. A., \& Berry, L. L. (1988). SERVQUAL: A Multiple-Item Scale for Measuring Customer Expectations of Service. Journal of Retailing, 64(1), 12-40

Siu, N. Y. M., \& Cheung, J. T. H. (2001). A measure of retail service quality. Marketing Intelligence \& Planning, 19(2), 88-96.http://dx.doi.org/10.1108/02634500110385327

Sohail, M. S. (2003). Service quality in hospitals: More favourable than you might think. Managing Service Quality, 13(3), 197-206. http://dx.doi.org/10.1108/09604520310476463

Sohail, M. S., \& Shaikh, N. M. (2004). Quest for excellence in business education: A study of student impressions of service quality. International Journal of Educational Management, 18(1), 58-65.http://dx.doi.org/10.1108/09513540410512163

Wangenheim, F., \& Bayon, T. (2007). The chain from customer satisfaction via word-of-mouth referrals to new customer acquisition. Journal of the Academy of Marketing Science, 35(2), 233-249.http://dx.doi.org/10.1007/s11747-007-0037-1

Wilson, A. M. (2002). Attitudes towards customer satisfaction measurement in the retail sector. International Journal of Market Research, 44(2), 213-222. 
Yap, K. B., Wong, D. H., Loh, C., \& Bak, R. (2010). Offline and online banking-where to draw the line when building trust in e-banking? International Journal of Bank Marketing, 28(1), 27-46.http://dx.doi.org/10.1108/02652321011013571

Zeithaml, V. A., Berry, L. L., \& Parasuraman, A. (1996). The behavioral consequences of service quality. The Journal of Marketing, 31-46. 